\title{
QUALITY CHARACTERISTICS OF BEEF HAMBURGER ENRICHED WITH RED GRAPE POMACE POWDER DURING FREEZING STORAGE
}

\author{
Omima S. Abdelhakam, Essam M. Elsebaie*, Adel K. Ghazi, Mahmoud S. Gouda
}

Department of Food Technology, Faculty of Agricultural, Kafrelsheikh University, 33516, Kafrelsheikh, Egypt

*Corresponding author, E-mail: Essam.Ahmed@agr.kfs.edu.eg

\begin{abstract}
Integrating the consumption of agro-industrial residues with satisfactory consumers is an opposition that, may affect the financial dividend of the frozen meat manufacturing, aside from producing products with diversified nutritional values and satisfying technical characteristics. Thence, we aimed in this research to elaborate and appraise the physicochemical and microbiological characteristics of beef hamburger with the addendum 2 and $4 \%$ of red grape pomace powder (RGPP) throughout its stockpiling at ($18 \pm 2^{\circ} \mathrm{C}$ ) over a period 12 weeks. A significant influence on $\mathrm{pH}$ value was observed at the beginning (zero time), however the control sample, $2 \%$ and $4 \%$ had $\mathrm{pH}$ values of 6.68 , 6.41 and 6.22, respectively. Meantime, there was a significant influence of (RGPP) on thiobarbituric acid (TBA) evidenced on 4th week. The results showed that the microbial growth increased as a function to storage period for all and the addendum of RGPP in beef burger caused a reduction in total bacterial count in comparison with control. Thus, in general, it can be concluded that addendum of RGPP is an efficacious mean to improve burger quality and increasing its storage stability.
\end{abstract}

Key words: beef burger; red grape pomace; storage stability

\section{Introduction}

Meat products can be suffered from numerous negative changes throughout frozen and refrigerated storage as a result for the growth of microorganisms and oxidation of lipids, which result in quality shortage, meat deterioration, and economical damage (1). The growth of microorganisms in meat and its other products may be lead to slime forming, degrading structural constituents, reduction in water holding capability, bad odor, and alteration in appearance and texture which decrease nutritive value, quality, and shelf- life (2). Lipid oxidation is contingent on the composition of fatty acids, the concentration of vitamin $\mathrm{E}$, and on oxidationenhancing substances such as free iron in the muscles. Oxidation products can lead to lose color and nutritional value as a result to the breakdown of lipids, proteins, pigments, vitamins and carbohydrates (3). The oxidative rancidity may be cause a lot of alterations in meat and their products ranged from large changes in flavor, color loss and structural breakdown for proteins (freshness losing) that impede consumer's repeated purchase (4). Artificial anti-oxidative substances such as butylated hydroxyanisole (BHA) and butylated hydroxytoluene (BHT) were utilized to hold up oxidation of li- 
pids in meat (5). Nonetheless, contemporary attention over its utilization has generated a necessity and induced research for alternate antioxidants, predominately from naturalistic origin. The usage of naturalistic preservatives with meat products increases the storage shelf life is a hopeful technology as numerous vegetative materials posse antimicrobial and antioxidant characteristics (6). Functional substances addendum into meat products might upgrade the health and nutritional attributes and extension their storage shelf-life (4).

Vegetation extracts which are affluent with polyphenolic components are perfect candidates, because of its extraction easiness from the naturalistic origins and their efficacy in the prevention of lipid oxidizing in food (6).

Grape seeds extract anti-oxidative efficacy has been assessed in a little number of meat sorts and was found to enhance the oxidative resistance in turkey patties (7), cooked beef (8) and nuggets (9).

Dietary fibers are considered to be a functional component of meat products. Incorporating fiber can get the texture, enhancing cooking performance because of its water binding and fat retention characteristic and dietary fibers can also produce technical characteristics that enhance physical, chemical and sensory attributes. Naturalistic antioxidants and dietary fibers are considered as dietetic agents that participate in enhancing human health. Natural products with high levels of phenolic antioxidants and dietary fibers are named antioxidant dietary fibers (ADF) (10).

The current investigation was intended to investigate the influence of red grape pomace powder (RGPP) integration in beef hamburgers on its physical, chemical, microbiological and sensory properties during frozen storage.

\section{Materials and methods}

Red grapes, variety Red Globe1, by products were obtained in August 2016 from Faragello factory for juice, Sixth of October City, Egypt. Red muscles beef, kidney fats and other components used for burger preparation were obtained from local market at Kafr El-Sheikh city,
Egypt. The beef meat and fat tissue were transported to the food technology laboratory, faculty of agriculture, Kafrelshiekh University using an icebox.

All chemicals used in this study of HPLC grade (99.9\% purity) were obtained from Sigma Company of chemicals and drugs, St. Louis, MO, USA.

\section{Preparation of samples}

The pomace (skin and seeds) was sorted by hand for removing stems and debris, and thereafter lyophilized, and milled up to pass through 20 mesh screen sieve. The yielded powder samples were mixed, and stored in polyethylene bags, then kept at room temperature until use (11) .

\section{Burger preparation}

Beef burger meat and kidney fat was grounded separately in a meat grinder by passing meat through a plate having $6 \mathrm{~mm}$ holes. The beef burger was formulated to contain the following ingredients $80 \%$ red muscles beef meat, $20 \%$ kidney fat, $18 \%$ (w/w) water (ice), $1.5 \%(\mathrm{w} / \mathrm{w})$ salt, ground black pepper $(0.3 \%)$, red pepper $(0.2 \%)$ and cumin $(0.2 \%)$ according to Aleson-Carbonell, et al.(12). The minced beef was treated with two concentrations of RGPP (2 and 4\%). Control without RGPP was used in all assays. The beef burgers were frozen at $-18^{\circ} \mathrm{C}$ until the start of analysis.

\section{Thermal treatment}

After the thawing at $4{ }^{\circ} \mathrm{C}$ for 12 hours, the beef burgers were stewed using an electrical grill (Genwex GW-066) at $220^{\circ} \mathrm{C}$ (the space between heat source and the samples was $4 \mathrm{~cm}$ ) for $8 \mathrm{~min}$ ( $4 \mathrm{~min}$ for each side of beef burgers) (2)

\section{Chemical analyses}

Gross chemical composition of red grape pomace powder was analyzed according to A.O.A.C. (13). Where, total carbohydrates were calculated by difference. The amount of total polyphenols was estimated as mg Gallic Acid Equivalent/100gm using the method outlined by González-Centeno et al (11). 


\section{Identification of phenolic acids}

For HPLC analysis, one gram of the red grape pomace powder was mixed with acidified methanol $(10 \mathrm{ml})$ for $4 \mathrm{~min}$ and centrifuged at $10000 \mathrm{rpm}$ for $10 \mathrm{~min}$ and the supernatant was filtered through a 0.2 um Millipore membrane. The filtrates were collected in a vial for injection into HPLC Hewllet packared (series 1050) equipped with auto-sampling injector, solvents (methanol and acetonitril) were degassed and ultraviolet (UV) detector was set at $280 \mathrm{~nm}$ and quarter HP pump. The column temperature was maintained at $35^{\circ} \mathrm{C}$, where gradient separation was performed using the mobile phase (methanol and acetonitril) at flow rate of $1 \mathrm{ml} / \mathrm{min}$ following the method of Goupy, et al. (14).

\section{Physical analyses of burger}

The $\mathrm{pH}$ value of beef hamburgers was determined by using a $\mathrm{pH}$ meter (Jenwae model 3357, USA) according to the method described by (15). Water holding capacity (WHC) was determined by filter press method as described by (15). Beef burgers were weighted before and after cooking to determine cook loss according to the method of ${ }^{15}$ by using the following equations:

Cooking loss $(\%)=[($ Raw weight - Cooking weight $) /$ Raw weight] ${ }^{*} 100$

\section{Chemical analyses of burger}

Thiobarbituric acid reactive substances (TBARS) of beef hamburger samples were estimated as reported by (16).

\section{Microbiological Analyses}

Total count of aerobic microorganisms and fungi and yeasts were carried out in triplicate and using the methodologies mentioned by (17).

\section{Statistical analysis}

General linear model of SPSS (Ver. 16.0, 2007) was used to conduct ANOVA for determination of differences between means. The probability levels of $\mathrm{P} \leq 01$ and $\mathrm{P} \leq 0.05$ were considered to be significant for statistical procedures. All measurements and trials were done in triplicate.

\section{Results and discussion}

Chemical composition of red grape pomace

There are many factors affecting the chemical composition of red grape pomace such as variation in organic compounds of the soil, varieties, fertilizers applied, climatic and environmental conditions (18).

The data in Table (1) indicate that pomace is considered a good source of protein, crude fiber and total carbohydrates which are important from the nutritional point of view. The results revealed that the moisture, crude protein, ether extract, ash, crude fiber and total carbohydrate contents were $5.1,12.5,11.5,1.8,9.2$ and $74.2 \%$, respectively. These results were in harmony with those of (19).

Identification of phenolic acids content of ethanolic red grape pomace powder extract

HPLC procedure was utilized for fractionation and identification of the phenolic components extricated from the tested sample. The results were tabulated in Table (2).

The results revealed that, red grape pomace ethanolic extract have 24 phenolic components. Pyrogallol was the highest compound of polyphenolic compounds found in ethanolic pomace extract (38.38\%) followed by Catechol (8.72\%) then Epicatechin (7.87\%), where Cinnamic $(0.09 \%)$ and Resveratrol $(0.15 \%)$ were the lowest ones. These results are in the same line with others obtained by (20).

\section{Physical analyses of burger}

Meat products physical characteristics such as $\mathrm{pH}$ and $\mathrm{WHC}$ are highly remarkable because of its influence on the quality attributes like cooking loss, juiciness and tenderness.

\section{$p H$ values}

The results in Table (3) revealed that there was an increment in beef hamburger $\mathrm{pH}$ values as a function of the storage time which on the same trend with (21) who stated that the inconsiderable increment in $\mathrm{pH}$ values throughout the storage period might be back to protein liberation metabolites as a consequence for bacterial efficiency. The results also appeared that 
the addendum of RGPP was performed to reduce beef hamburger $\mathrm{pH}$ values. Also, there was a decrement in $\mathrm{pH}$ values as a function for increasing the addendum levels of RGPP as compared to control treatment which has the highest $\mathrm{pH}$ values along storage period whereas beef hamburger containing $4 \%$ RGPP treatment has the lowest $\mathrm{pH}$ values. This $\mathrm{pH}$ decrement might be lead to the low $\mathrm{pH}$ values of RGPP added (22). At the end of storage time, the $\mathrm{pH}$ value of the control sample was 6.93 which significantly different from the $\mathrm{pH}$ value of beef hamburger enriched with $4 \%$ RGPP (6.51).

\section{Water holding capacity (WHC)}

The results given in Table 3 appeared that WHC $\left(\mathrm{cm}^{2}\right)$ of beef hamburger has been reduced along the storage period. This decrement may be back to proteins denaturation which causing a reduction in its ability to hold water leading to lower WHC. The addendum of RGPP into beef hamburger negatively influence on WHC which was reduced with increasing the addendum level of RGPP, Beef hamburger enriched with $4 \%$ RGPP has achieved the lowest WHC values (the highest area of squeezed water) during storage period whereas control treatments were recorded the highest values which appear that RGPP had lower water holding capacity.

Table 1: Proximate chemical composition of red grape pomace (on dry weight basis)

\begin{tabular}{ll}
\hline Component & $\%$ \\
\hline Moisture & 5.1 \\
Crude protein $(\mathrm{N} x$ 6.25) & 12.5 \\
Ether extract & 11.5 \\
Ash & 1.8 \\
Crude fiber & 9.2 \\
*Total carbohydrates & 74.2 \\
Total polyphenols (mg GAE/g) & 4.92 \\
\hline
\end{tabular}

*Total carbohydrates were calculated by difference.

Table 2: Phenolic compounds in ethanolic extract of red grape pomace powder

\begin{tabular}{llll}
\hline Compounds & $\begin{array}{l}\% \text { of the Total } \\
\text { phenolics }\end{array}$ & Compounds & $\begin{array}{l}\% \text { of the Total } \\
\text { phenolics }\end{array}$ \\
\hline Gallic acid & 3.64 & Ferulic & 0.62 \\
4-Amino benzoic acid & 0.20 & Isoferulic & 1.76 \\
Protocatchuic & 2.72 & Resveratrol & 0.15 \\
Catechin & 6.77 & Ellagic & 4.29 \\
Chlorogenic & 4.00 & Alpha-Coumaric & 1.18 \\
Catechol & 8.72 & e-Vanillic & 4.70 \\
Epicatechin & 7.87 & Benzoic & 7.58 \\
Caffeine & 0.68 & 3,4,5 Methoxycinnamic & 0.38 \\
Caffeic & 1.14 & Coumarin & 0.31 \\
Vanillic & 1.96 & Salicylic & 1.56 \\
$\beta$-coumaric acid & 0.34 & Cinnamic & 0.09 \\
Pyrogallol & 38.38 & P-OH-benzoic & 0.92 \\
\hline
\end{tabular}


Table 3: Changes in some physical characteristics of beef hamburger enriched with red grapes pomace powder throughout frozen storage

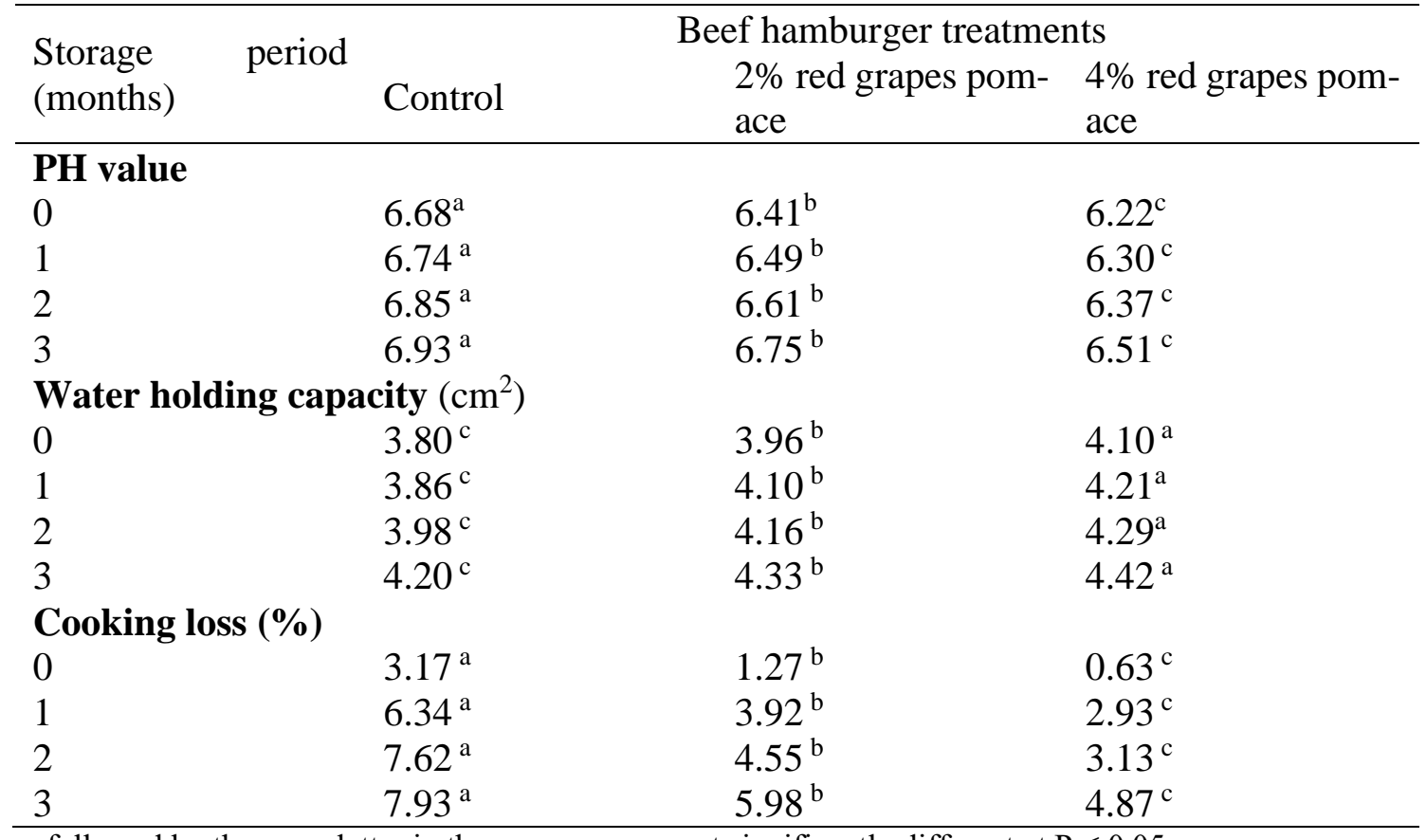

Values followed by the same letter in the same row are not significantly different at $\mathrm{P} \leq 0.05$

Table 4: Changes in TBA values (mg malonaldehyde / $\mathrm{kg}$ ) of beef hamburger enriched with red grapes pomace powder during frozen storage

\begin{tabular}{lllll}
\hline Beef burger type treatments & \multicolumn{5}{l}{ Storage period per months } \\
\cline { 2 - 5 } & 0 & 1 & 2 & 3 \\
Control & $0.367^{\mathrm{a}}$ & $0.595^{\mathrm{a}}$ & $0.709^{\mathrm{a}}$ & $0.932^{\mathrm{a}}$ \\
$2 \%$ red grapes pomace & $0.352^{\mathrm{b}}$ & $0.470^{\mathrm{b}}$ & $0.501^{\mathrm{b}}$ & $0.600^{\mathrm{b}}$ \\
$4 \%$ red grapes pomace & $0.338^{\mathrm{c}}$ & $0.396^{\mathrm{c}}$ & $0.412^{\mathrm{c}}$ & $0.563^{\mathrm{c}}$ \\
\hline
\end{tabular}

Table 5: Changes in microbiological properties of beef hamburger incorporated with red grapes pomace powder during frozen storage

\begin{tabular}{|l|l|l|l|}
\hline $\begin{array}{l}\text { Storage period } \\
\text { (months) }\end{array}$ & control & $\begin{array}{l}2 \% \text { red grapes pom- } \\
\text { ace }\end{array}$ & $\begin{array}{l}\text { 4\% red grapes pom- } \\
\text { ace }\end{array}$ \\
\hline \multicolumn{4}{|l|}{ Plate count bacteria (log cfu/g) } \\
\hline 0 & 3.21 & 3.21 & 3.21 \\
\hline 1 & 3.89 & 3.00 & 2.93 \\
\hline 2 & 4.96 & 2.88 & 2.68 \\
\hline 3 & 6.42 & 2.61 & 2.44 \\
\hline Yeast and molds count (log cfu/g) & \multicolumn{2}{l|}{} \\
\hline 0 & 2.20 & 2.20 & 2.20 \\
\hline 1 & 3.40 & 2.18 & 1.90 \\
\hline 2 & 3.62 & 1.93 & 1.80 \\
\hline 3 & 4.70 & 1.70 & 1.65 \\
\hline
\end{tabular}




\section{Cooking loss}

According to data in Table (3), cooking loss percentage of beef hamburger is increased as a function of the storage period which on the line with the water holding capacity results. Also, the cooking loss of beef hamburger enriched with RGPP is decreased with increasing the addendum levels since beef hamburger enriched with RGPP had cooking loss values lower than control treatment along the storage period. Burger containing $4 \%$ RGPP had the lowest cooking loss values at any storage period while, control treatment have the highest cooking loss value. This might be back to the fiber components of RGPP, which could influence on the cooking loss of the beef hamburger, since fibers could reduce the water loss during cooking by forming gels as reported by (22).

\section{Changes in chemical properties of beef hamburger during frozen storage}

\section{Thiobarbituric acid (TBA) value}

Lipid oxidation is one of the main limiting factors for the quality and acceptability of meat and meat products. Thiobarbituric acid (TBA) value (malonaldehyde / $\mathrm{kg}$ ) is used as an index for measuring oxidative rancidity which takes place in meat products during storage.

Table (4) shows the effect of incorporation of RGPP on the oxidative stability of beef hamburger during frozen storage. The data show that the TBA value is increased as the storage time increased which in agree with (21). The TB A values of beef hamburger were decreased with increasing RGPP incorporation level. There are significant differences between control and the other red grapes pomace powder containing treatments exhibited lower TBA values than control treatments. These due to that polyphenols have been re-ported to have antioxidant activity in vitro (23).

At the end of frozen storage period TBA values of control was higher than the spoilage limit of Egyptian Standard Specifications (ESS) (24) (0.9 mg malonaldehyde / kg) since it recorded $0.932 \mathrm{mg}$ malonaldehyde / kg. On the other hand beef hamburger treatments contain-ing 2 and $4 \%$ RGPP were reached to $62-66 \%$ of the ESS spoilage limit. These results may be due to the polyphenol content of red grapes pomace powder which play important role in reducing the oxidative reaction of lipids which reflects in low TBA values. The data also show that at any storage time the lowest TBA value was observed for beef hamburger containing $4 \%$ RGPP.

\section{Changes in microbiological load of beef hamburger incorporated with red grapes pomace powder during frozen storage}

Table (5) shows the effect of incorporation of red grapes pomace powder (RGPP) on the microbial growth of beef hamburger during frozen storage. The results show that as the storage time increase the microbial growth increase for all treatments. The incorporation of red grapes pomace powder in beef hamburger results in lowering the total bacterial count as compared to control, since it was gradual decreasing as the RGPP incorporation level increased. This may be due to the higher phenolic compounds content in beef hamburger incorporated with RGPP. The results show that there are significant differences between all treatments. At any storage time the lowest total bacterial count was observed for beef burger incorporated with $4 \%$ RGPP while the highest bacterial co unt was observed for control treatment which reached the spoilage limit of ESS (24) (6 log cfu/g) for total bacterial count at $90 \mathrm{~d}$ ays of frozen storage whereas treatments incorporated with RGPP reached to $30-35 \%$ o f this limit. Also, the molds and yeasts counts were decreased as the incorporation level increased, the lowest counts were observed for treatment incorpor ated with $4 \%$ RGPP at all sto rage times. At the end of storage period there were significant differences between control and treatments incorporated with RGPP.

\section{Conclusion}

The results of this study demonstrated that red grape pomace ethanolic extract contains 24 phenolic components. These compounds helped to improve pomace powder extract as antioxidant agent that can be used to prepare functional foods which provide the physical, chemical and microbiological properties of beef hamburger. 


\section{Conflict of interest}

Authors declare that no conflict of interest.

\section{References}

1. Essa RY, Elsebaie E. Effect of Using Date Pits Powder as a Fat Replacer and Anti-Oxidative Agent on Beef Burger Quality. J Food and Dairy Sci, Mansoura Univ 2018;9:91-6.

2. Oliveira RBSd, Lucia FD, Ferreira EB, et al. Quality of beef burger with addition of wet okara along the storage. Ciência e Agrotecnologia 2016;40:706-17.

3. Dave D, Ghaly AE. Meat spoilage mechanisms and preservation techniques: a critical review. American Journal of Agricultural and Biological Sciences 2011;6:486-510.

4. Quevedo R, Pedreschi F, Valencia E, et al. Kinetic modeling of deterioration of frozen industrial burgers based on oxidative rancidity and color. Journal of Food Processing and Preservation 2018:e13655.

5. Pereira D, Pinheiro RS, HELDT LFS, et al. Rosemary as natural antioxidant to prevent oxidation in chicken burgers. Food Science and Technology (Campinas) 2017:0-0.

6. Nowak A, Czyzowska A, Efenberger M, et al. Polyphenolic extracts of cherry (Prunus cerasus L.) and blackcurrant (Ribes nigrum L.) leaves as natural preservatives in meat products. Food microbiology 2016;59:142-9.

7. Nardoia M, Ruiz-Capillas C, Herrero AM, et al. Effect of added grape seed and skin on chicken thigh patties during chilled storage. International Journal of Food and Nutritional Science 2017;4: 0.

8. Cosansu S, Juneja VK. Growth of Clostridium perfringens in sous vide cooked ground beef with added grape seed extract. Meat science 2018; 143:252-6.

9. Cagdas E, Kumcuoglu S. Effect of grape seed powder on oxidative stability of precooked chicken nuggets during frozen storage. Journal of food science and technology 2015;52:2918-25.

10. Mehta N, Ahlawat S, Sharma D, et al. Novel trends in development of dietary fiber rich meat products - a critical review. Journal of Food Science and Technology 2015;52:633-47.

11. González-Centeno M, Comas-Serra F, Femenia A, et al. Effect of power ultrasound application on aqueous extraction of phenolic compounds and antioxidant capacity from grape pomace (Vitis vinifera L.): experimental kinetics and modeling. Ultrasonics sonochemistry 2015;22:506-14.
12. Aleson-Carbonell L, Fernández-López J, Pérez-Alvarez J, et al. Characteristics of beef burger as influenced by various types of lemon albedo. Innovative Food Science \& Emerging Technologies 2005;6:247-55.

13. A.O.A.C. Association of Official of Analytical Chemists, Official Methods of Analysis. 18th Ed., Pub. By the A.O.A.C.: Arlington, Virginia, 2220 USA., 2010.

14. Goupy $\mathrm{P}$, Hugues $\mathrm{M}$, Boivin $\mathrm{P}$, et al. Antioxidant composition and activity of barley (Hordeum vulgare) and malt extracts and of isolated phenolic compounds. Journal of the Science of Food and Agriculture 1999;79:1625-34.

15. Pinero M, Parra K, Huerta-Leidenz N, et al. Effect of oat's soluble fibre ( $\beta$-glucan) as a fat replacer on physical, chemical, microbiological and sensory properties of low-fat beef patties. Meat science 2008;80:675-80.

16. Trindade R, Mancini-Filho J, Villavicencio A. Natural antioxidants protecting irradiated beef burgers from lipid oxidation. LWT-Food Science and Technology 2010;43:98-104.

17. Georgantelis D, Blekas G, Katikou P, et al. Effect of rosemary extract, chitosan and $\alpha$ tocopherol on lipid oxidation and colour stability during frozen storage of beef burgers. Meat Science 2007;75:256-.64

18. Howard L, Talcott S, Brenes C, et al. Changes in phytochemical and antioxidant activity of selected pepper cultivars (Capsicum species) as influenced by maturity. Journal of Agricultural and Food Chemistry 2000;48:1713-20.

19. Silvia PM, Ioan PM. The Chemical Composition Assessment Of The Feteasc Neagr Grape Pomace And Its Fractions Obtained From Wine Industry In Different Years. Analele Stiintifice ale Universitatii" Al I Cuza" Din Iasi(Serie Noua) Sectiunea 2 a Genetica si Biologie Moleculara 2015;16:167.

20. Lafka T-I, Sinanoglou V, Lazos ES. On the extraction and antioxidant activity of phenolic compounds from winery wastes. Food Chemistry 2007;104:1206-14.

21. Kalaikannan A, Anjaneyulu A, Santhi D. Effect of egg proteins on the quality and refrigerated storage life of chicken patties made with broilerspent hen meat and by-products. International journal of food science \& technology 2007;42:57986.

22. García ML, Calvo MM, Selgas MD. Beef hamburgers enriched in lycopene using dry tomato peel as an ingredient. Meat science 2009;83:45-9. 
23. Powell ZD, Lakesha C. Antioxidant capacityof lycopene-containing foods. International journal of food sciences and nutrition 2001; 52:143-9.
24. ESS. Egyptian Standard Specifications, No. 439, 2005/Thermally treated.treated poultry meat products. 2005. 